\title{
APPLICATIONS OF HAUSDORFF MEASURE OF NONCOMPACTNESS IN THE SPACES OF GENERALIZED MEANS
}

\author{
M. MursaleEn And Abdullah K. Noman
}

Abstract. In this paper, we derive some identities for the Hausdorff measures of noncompactness of certain matrix operators on the sequence spaces $X(r, s)$ of generalized means. Further, we apply the Hausdorff measure of noncompactness to obtain the necessary and sufficient conditions for such operators to be compact.

Mathematics subject classification (2010): 46B15, 46B45, 46B50.

Keywords and phrases: $B K$ space, generalized means, matrix transformation, Hausdorff measure of noncompactness, compact operator.

\section{REFERENCES}

[1] F. BAŞAR AND E. MALKOWSKY, The characterization of compact operators on spaces of strongly summable and bounded sequences, Appl. Math. Comput. 217 (2011), 5199-5207.

[2] M. BAŞARIR AND E. E. KARA, On compact operators on the Riesz $B^{m}$-difference sequence spaces, Iranian Journal of Science \& Technology 35, A4 (2011), 279-285.

[3] H. BILGIÇ AND H. FuRKAN, On the fine spectrum of the generalized difference operator $B(r, s)$ over the sequence spaces $\ell_{p}$ and $b v_{p}(1<p<\infty)$, Nonlinear Anal. 68, 3 (2008), 499-506.

[4] E. E. KARA AND M. BAŞARIR, On some Euler $B^{(m)}$ difference sequence spaces and compact operators, J. Math. Anal. Appl. 379 (2011), 499-511.

[5] B. DE MALAFOSSE AND V. RAKOČEVIĆ, Applications of measure of noncompactness in operators on the spaces $s_{\alpha}, s_{\alpha}^{0}, s_{\alpha}^{(c)}, \ell_{\alpha}^{p}$, J. Math. Anal. Appl. 323, 1 (2006), 131-145.

[6] E. MalKowsKy AND V. RAKOČEVIĆ, An introduction into the theory of sequence spaces and measures of noncompactness, Zbornik radova 9(17), Mat. institut SANU (Beograd), 2000, pp. 143-234.

[7] E. Malkows Ky, V. RakočEviĆ AND S. ŽIVković, Matrix transformations between the sequence space $b v^{p}$ and certain BK spaces, Bull. Cl. Sci. Math. Nat. Sci. Math. 123, 27 (2002), 33-46.

[8] M. Murs aleen, V. Karakaya, H. Polat And N. Simşek, Measure of noncompactness of matrix operators on some difference sequence spaces of weighted means, Comput. Math. Appl. 62 (2011), 814-820.

[9] M. Murs aleen And S. A. Mohiuddine, Applications of measures of noncompactness to the infinite system of differential equations in $\ell_{p}$ spaces, Nonlinear Anal. 75 (2012), 2111-2115.

[10] M. Murs aleen AND A. K. Noman, Compactness by the Hausdorff measure of noncompactness, Nonlinear Anal. 73(8) (2010), 2541-2557.

[11] M. Mursaleen AND A. K. Noman, On generalized means and some related sequence spaces, Comp. Math. Appl. 61, 4 (2011), 988-999.

[12] M. MURSALEEN AND A. K. NOMAN, The Hausdorff measure of noncompactness of matrix operators on some BK spaces, Operators and Matrices 5, 3 (2011), 473-486.

[13] M. Mursaleen AND A. K. Noman, On $\sigma$-conservative matrices and compact operators on the space $V_{\sigma}$, Appl. Math. Lett. 24 (2011), 1554-1560.

[14] M. Mursaleen And A. K. Noman, Compactness of matrix operators on some new difference sequence spaces, Linear Algebra Appl. 436, 1 (2012) 41-52.

[15] V. RAKOČEVIĆ, Measures of noncompactness and some applications, Filomat 12, 2 (1998), 87-120.

[16] M. Stieglitz And H. Tietz, Matrixtransformationen von folgenräumen eine ergebnisübersicht, Math. Z. 154 (1977), 1-16. 
[17] A. Wilansky, Summability through Functional Analysis, in: North-Holland Mathematics Studies, vol. 85, Elsevier Science Publishers, Amsterdam, New York, Oxford, 1984. 